Висновки. Розглянувши процес автоматизації створення бібліографічного опису авторефератів, зауважимо, що він має певні переваги та недоліки. Зокрема, висококваліфіковані та досвідчені каталогізатори ставлять під сумнів можливість економії часу, стверджуючи, що за допомогою наведеного методу 50 авторефератів можна опрацювати за дві-три години, тоді як віртуози своєї справи здатні зробити це швидше.

До переваг належать такі:

— автоматизація рутинної роботи зі створення запису автореферату;

- економія кадрового ресурсу, адже не потрібен фахівець вищої кваліфікації, який швидко й чітко опрацьовує такі документи;
- запропонований метод не втрачає актуальності за тотальної диджиталізації [2; 3], оскільки створення електронного запису значно прискорює пошук серед повних текстів. Якщо в майбутньому бібліотеки отримуватимуть цифрові версії документів, це дасть змогу спростити процеси автоматизованого створення бібліографічного запису завдяки тому, що такі ланки, як сканування та розпізнавання документів стануть зайвими.

Коли запис створено, слід скорегувати неточно розпізнані поля: назва, автор, колективний автор тощо, а також дані про номер акту NNN КСО (рис. 4) для всіх записів партії та інвентарний номер (999999) для кожного запису.

Список використаних джерел

1. Основні вимоги до дисертацій та авторефератів дисертацій // Бюлетень ВАК України. — 2007. — № 6. - С. 9-17 ; Бюлетень ВАК України. — 2009. — № 5. — С. 26-30 ; Бюлетень ВАК України. — 2011. — № 9-10. - С. 2-10. — Режим доступу: http://anu.edu.ua/uploads/aspirantura-17-18/19720.pdf. - Назва з екрана.

2. Слово року 2019. - Режим доступу: http://myslovo.com/?page_id=4634. - Назва з екрана.

3. Володимир Зеленський: Наша глобальна мета - побудувати країну з добре розвинутою цифровою економікою. Режим доступу: https://www.president.gov.ua/news/volodimir-zelenskij-nasha-globalna-meta-pobuduvati-krayinu-z-58593. Назва з екрана.

\title{
Oleksandr Kuznetsov Automation of creation bibliographic description of dissertation abstracts
}

The article deals with the optimization of the cataloging process of dissertation abstracts at the State Scientific and Technical Library (SSTL) of Ukraine. Automation of entering bibliographic descriptions of dissertation abstracts into the database is based on the fact that according to the current rules a bibliographic description of the publication is created from the title page. However, abstracts do not have a cover sheet, so the main information is taken from the cover. According to the rules for composing a thesis abstract, the title page is designed so that each paragraph contains certain bibliographic information.

The process of automating the creation of a bibliographic description of abstracts, in fact, involves the programmatic placement of indices of division in the text from the covers of these documents, which facilitates their further import into the relevant database.

The analyzed automated abstract introduction process was developed with the help of VBA software for Word and tested in the Scientific Research and Development Fund department of the SSTL.

Keywords: cataloging; abstracts; automation; bibliographic description; algorithm; coding

\section{References}

1. Osnovni vimogi do disertacij ta avtoreferativ disertacij (2019). Byuleten VAK Ukrayini, 2007, 6, pp. 9-17 ; Byuleten VAK Ukrayini, 2009, 5, pp. 26-30 ; Byuleten VAK Ukrayini, 2011, 9-10, pp. 2-10. Available at: http://anu.edu.ua/ uploads/aspirantura-17-18/19720.pdf.

2. Slovo roku 2019. (2019). Available at: http://myslovo.com/?page_id=4634.

3. Volodimir Zelenskij: Nasha globalna meta - pobuduvati krayinu z dobre rozvinutoyu cifrovoyu ekonomikoyu (2019). Available at: https://www.president.gov.ua/news/volodimir-zelenskij-nasha-globalna-meta-pobuduvati-krayinu-z-58593.

Надійшла до редакції 8 січня 2020 року

УДК 004:338.436](477)(045)

DOI: $10.36273 / 2076-9555.2020 .2(283) .37-42$

Оксана Капралюк,

кандидат сільськогосподарських наук, завідувач відділу науково-методичної роботи та наукового реферування Начіональної наукової сільськогосподарської бібліотеки НААН, e-mail: Oksanulichka@bigmir.net ORCID: https://orcid.org/0000-0002-2034-8958

\section{Система науково-інформаційного забезпечення агропромислового комплексу Украӥни}

У статті проаналізовано сучасний стан інформаційних ресурсів, сформованих на різних рівнях управління. Наведено характеристику національної системи науково-технічної інформачії (НTI) з питань сільського господарства. Зазначено, що ї̈ головними користувачами є вчені; товаровиробники; керівники, менеджери; висвітлено особливості забезпечення інформаційних потреб иъього сегмента. Зауважено, що серед галузевих інформаційних систем важливу роль у розвитку агропромислового комплексу країни (АПК) відіграють інформачійні системи: Міністерства розвитку економіки, торгівлі та сільського господарства України, Міністерства освіти і науки Украӥни, Національної академії аграрних наук України, 
а також підпорядкованих ним організачій $і$ установ, аграрних книгозбірень, дорадчих служб, УкрІНТЕІ, УкрНДНЦ, Держстату, галузевих асочіачій, інформаційних порталів, щз в сукупності утворюють інтегровану інформачійну систему. Ефективне та якісне забезпечення інформачійних потреб спечіалістів АПК неможливе без інформаційних ресурсів, за зберігання й нагромадження яких традичійно відповідають галузеві бібліотеки на чолі з Начіональною науковою сільськогосподарською бібліотекою (ННСГБ) НААН. Пріоритетним напрямом діяльності установи є розкриття та репрезентація фонду наявних документів, а також забезпечення доступу до нього иирокого кола фізичних $i$ віртуальних користувачів. Відповідно до цього завдання здійснюється активне формування електронної бази даних "ЕК Украгротека", загальний обсяг якої становить понад 550 тис. записів, із них 52 тис. 一 на повнотекстові видання. Успішно реалізуються завдання шуодо створення національної сільськогосподарської бібліографії, репрезентованої 13 біобібліографічними серіями. Від 1999 р. щуоквартально виходить друком реферативний журнал "Агропромисловий комплекс України".

Ключові слова: національні інформаційні ресурси з питань сільського господарства; користувачі інформації; генератори галузевої інформачії; ННСГБ НААН; електронний каталог "Украгротека"; бази даних (БД); електронні інформачійні ресурси; мережа аграрних бібліотек

Постановка проблеми. Для України пріоритетним і стратегічно важливим сектором економіки традиційно залишається агропромисловий комплекс, що є складною виробничо-економічною системою. Успіх функціонування кожної 3 підсистем та їх взаємодія зумовлені ефективністю координації й консолідації зусиль усіх інфраструктурних елементів, достовірністю моніторингу, а також оперативністю та якістю науково-інформаційного забезпечення.

Аналіз попередніх досліджень і публікацій. Значний внесок у поширення сільськогосподарських знань та інформації зробили О. Чаянов, О. Яната, В. Дерлеменко та інші.

Зокрема, економіст О. Чаянов 1917 р. видав підручник 3 організації діяльності сільськогосподарської консультаційної служби, головне призначення якої вбачав у підвищенні спроможності виробників-аграріїв самостійно ухвалювати управлінські рішення.

Вагомий внесок у формування галузевого документопотоку зробив О. Яната — відомий агроном, професор, один 3 організаторів радянської сільськогосподарської науки, репресований 1936 р. У 1915 р., виступаючи на з'їзді Харківського товариства писемності, О. Яната запропонував сміливі на той час рішення: для підготовки інтелігентних працівників, які мали поширювати серед народу знання 3 природознавства, агрономії та інших наук позашкільним шляхом, слід було всі типи шкіл — від нижчих до вищих, як загальні, так і спеціальні - наблизити до потреб прилеглих до них районів, їх обслуговування мало стати завданнями школи.

Варто також згадати доктора педагогічних наук В. Дерлеменка, який присвятив свої розвідки дослідженню системи поширення знань із питань сільського господарства.

Проте у працях зазначених науковців порушену проблематику висвітлено не комплексно, лише окремі iii складники, тому актуальною є потреба системного й грунтовного розгляду окресленого питання.

Мета статті - вивчення системи науково-інформаційного забезпечення агропромислового комплексу України.

Виклад основного матеріалу дослідження. На нинішньому етапі головними користувачами науковотехнічної інформації в галузі сільського господарства є три категорії, відповідно до характеру діяльності: вчені; товаровиробники; керівники, менеджери [1].
Зазначені цільові аудиторії потребують різних джерел інформації, методики ії добору та використання. Наприклад, товаровиробники розв'язують конкретні завдання, сформульовані замовниками, в терміни, встановлені планами. Вони послуговуються науково-технічною та виробничою інформацією, що має бути комплексною, охоплювати поле різних наукових дисциплін і галузей знань та містити конкретні відомості про методи й засоби виконання завдань. Товаровиробникам зазвичай бракує часу на грунтовний перегляд літератури, їм більшою мірою, ніж науковцям необхідна допомога в пошуку важливої інформації та отриманні їі у зручній для використання формі.

Інформаційне забезпечення керівників також має певні особливості. По-перше, обслуговуючи цей сегмент, працівники бібліотеки зазвичай стикаються 3 ситуацією, за якої НTI, хоча і $є$ важливим, але далеко не головним складником у структурі інформаційного супроводу, оскільки навіть у процесі управління академічною чи освітньою установою, окрім наукової, важливою є економічна, соціально-політична, адміністративна та інші види інформації. По-друге, інформація про досягнення науки й техніки, котрою послуговуються керівники, значно відрізняється за характером від науково-технічної, що ії використовують учені, оскільки має пропонувати варіанти розв'язання проблеми та усунення ії наслідків. Такі відомості містять не статті та книги, а огляди й прогнози.

Користувачі-науковці у процесі дослідження прагнуть віднайти закономірність у явищах, зрозуміти їхню природу, унормувати структуру сучасних знань відповідно до наукової парадигми, в межах якої працюють. Цьому сегментові потрібні відомості 3 конкретного питання, що відрізняються повнотою й широким спектром проблематики. Дослідники прагнуть шукати їх самостійно й використовують здебільшого періодичні видання, книги, звіти, описи винаходів тощо. Інформаційне забезпечення науковців залежить від цільового призначення досліджень, зокрема фундаментальних чи прикладних [2].

Вагому роль у науково-інформаційному забезпеченні відіграє вибір каналу комунікації з цільовою аудиторією. Зауважимо, що нині найважливішою ланкою в галузевій системі комунікацій є електронні ресурси - бібліографічні, повнотекстові БД тощо, котрі охоплюють дедалі більшу частку в структурі інформаційної бази. Аналіз, проведений О. Лаврик, 
свідчить, що науковці надзвичайно цінують інтернет як спосіб отримання багатоаспектної інформації. I хоча поширена думка, що безпосереднє спілкування з ученими всього світу не спроможні замінити ані читання наукових статей, ані завантаження 3 мережі, результати дослідження О. Лаврик переконують у протилежному. Аналіз виявив, що в науковому середовищі найпопулярнішими каналами є віддалені повнотекстові й бібліографічні БД, електронні колекції та архіви, доступні через інтернет (46\%) [2].

Щодо інформаційної підтримки АПК, то головним органом у системі виконавчої влади 3 питань формування та забезпечення реалізації державної аграрної політики, продовольчої безпеки країни, державного управління у сфері агропромислового виробництва до початку вересня 2019 р. було Міністерство аграрної політики та продовольства України, діяльність якого спрямовував і координував Кабінет Мiністрів України. Проте з метою оптимізації системи центральних органів виконавчої влади Кабмін вирішив реорганізувати Мінагрополітики через приєднання до Міністерства розвитку економіки, торгівлі та сільського господарства України, що стало правонаступником його майна, прав і обов'язків. Отже, вважаємо за доцільне докладно розглянути аспекти інформаційного забезпечення АПК Мінагрополітики.

Пріоритетним напрямом діяльності зазначеного Міністерства було забезпечення прозорості дій та оперативної взаємодії з громадянами. Зокрема, 14.09.2015 розпочав функціонувати інформаційний центр, що мав надавати комплексні відомості про діяльність Мінагрополітики та його структурних підрозділів, а також консультувати представників аграрного бізнесу та громадян 3 низки питань, пов'язаних із реєстрацією сільгосппідприємств, порядком здійснення господарської діяльності, виходом на закордонні ринки, зеленим туризмом тощо.

До інфоцентру регулярно надходили актуальні дані щодо діяльності Міністерства від відповідальних департаментів [3]. Наприклад, за даними звіту про надходження інформаційних запитів за IV квартал 2018 р. на адресу Мінагрополітики надійшло 140 запитів на інформацію поштою, електронною поштою, телефоном, факсом, з яких: 30 - від Кабінету Міністрів України; 93 - від громадян; 39 - від громадських організацій; 8 - від редакцій журналів і газет.

На запити надано відповіді та роз'яснення, зокрема 3 питань щодо: площі сільськогосподарських земель 3 органічним статусом в Україні; порядку отримання компенсації витрат на проєктні роботи садівництва; найрентабельніших сільськогосподарських культур 2016-2018 рр.; погодження правил виробництва коньяків України; використання аграрних розписок в Україні впродовж 2016-2018 pp. [4].

Мінагрополітики разом із представниками Офісу підтримки реформ (Reform Support Team, RST) і за сприяння Продовольчої та сільськогосподарської організації ООН (ФАО) (Food and Agriculture Organization, FAO) створили допоміжний інформаційний ресурс для стейкхолдерів агросектору, розрахований на ко- ристувачів, які шукають конкретні відомості щодо практичних аспектів ведення агробізнесу в Україні [5].

Важлива роль в інформаційній підтримці вітчизняного АПК також належить Національній академії аграрних наук України (НААН), що забезпечує проведення фундаментальних і прикладних наукових досліджень із питань розвитку галузей АПК, використання природних ресурсів, охорони довкілля, соціального розвитку сільських територій тощо. Ці завдання виконують науково-дослідні установи (НДУ), державні підприємства й дослідні господарства, підпорядковані НААН [6].

Одним зі шляхів поширення інформації про наукові здобутки НДУ НААН є виставки. Наприклад, 33 наукові установи Академії взяли участь у XXX Міжнародній агропромисловій виставці "Агро-2018". У рамках зазначеного заходу на 6 тематичних експозиціях було репрезентовано науково-технічні розробки 29 інститутів і 4 дослідних станцій НААН. Упродовж 2018 р. установи НААН пропагували вітчизняні наукові досягнення на регіональних, всеукраїнських і міжнародних виставкових заходах, зокрема: Національній спеціалізованій виставці "Україна аграрна — 2018"; Національній спеціалізованій виставці "Україна зернова - 2018", XV Міжнародній агропромисловій виставці "Агрофорум - 2018"; сільськогосподарській виставці "Фермер України — 2018"; Міжнародному науковотехнологічному форумі "Наука, інновації, технології - 2018".

Інформування про результати виконаних НДР у друкованих працях $є$ не лише невіддільним складником поширення наукових знань, а й важливою умовою кар'єрного зростання вченого. У 2018 р. наукові установи Академії видали 168 книг, із них: 156 - в Україні, 12 - в інших країнах; 151 науковий журнал, 73 міжвідомчі наукові збірники, 72 бюлетені та 54 методичні рекомендації.

Державне видавництво "Аграрна наука" НААН забезпечило підготовку оригінал-макетів і випуск наукової літератури загальним обсягом 442,9 обл.-вид. арк., із них 25 найменувань наукових видань обсягом 231 обл.-вид. арк. [7].

Поширення галузевих знань та інформації закладами вищої освіти (3ВО) I-IV р. а. що становлять майже 16\% ЗВО України, відбувається: через підготовку кадрів із неповною вищою, базовою вищою, повною вищою освітою, а також робітників для агропромислової та природоохоронної галузі; підвищення кваліфікації та перепідготовку фахівців для сільського, лісового, рибного господарств, ветеринарної медицини й природоохоронної галузі; підготовку, перепідготовку та атестацію науково-педагогічних i наукових працівників вищої кваліфікації для університетів, інших навчальних закладів та наукових установ; організацію та проведення науково-дослідних робіт з урахуванням досвіду провідних іноземних університетів дослідного типу; організацію та проведення конференцій, симпозіумів, конгресів, зокрема міжнародних; випуск наукових праць педагогічних, наукових і науково-педагогічних працівників 3ВО, матеріа- 
лів конференцій, симпозіумів, нарад, тематичних збірників, наукових звітів та інших видань із питань розвитку аграрної сфери, економіки, охорони довкілля, соціального розвитку села.

Дієвим інструментом поширення знань із питань сільського господарства $\epsilon$ наукові парки, сформовані на базі 3ВО. Інтелектуальна власність галузевих закладів вищої освіти I-IV p. а., як і науково-дослідних установ, слугує додатковим механізмом упровадження створюваних ними знань на практиці.

Враховуючи той факт, що ЗВО мають стати драйверами інновацій, що $є$ рушійними силами розвитку регіонів, Президія Ради проректорів із наукової роботи рішенням від 21.03.2017 зініціювала підготовку й видання інформаційного збірника "Інноваційні розробки університетів і наукових установ МОН України".

Основний зміст довідника становлять відомості про 240 розробок, надані університетами й науковими установами. Інформацію структуровано за такими тематичними розділами: агропромисловий комплекс $\mathrm{i}$ біотехнології; наукові інформаційно-комунікаційні технології; енергетика та енергоефективність; машинобудування; приладобудування тощо. Зазначимо, що прийняте структурування збірника корелює 3 результатами форсайтного дослідження, проведеного під керівництвом академіка М. Згуровського, що виявило дев'ять кластерів вітчизняної економіки, 3 якими Україна може інтегруватися в міжнародну кооперацію, а саме: аграрний та військово-промисловий комплекс; інформаційно-телекомунікаційні технологіі; нанотехнології та створення нових речовин і матеріалів; зелена енергетика; високотехнологічне машинобудування; розвиток транзитної інфраструктури, науки про життя, туризм. Отже, наукові розробки закладів вищої освіти та наукових установ відповідають перспективним напрямам вітчизняної економіки [8].

Утім, результативність інноваційної діяльності ЗВО та НДУ залишається низькою, піi основним результатом $€$ обсяг інноваційної продукції, котру реалізують підприємства. Першорядними чинниками, що гальмують упровадження інноваційної політики в державних установах, $\epsilon$ мінімальна фінансова підтримка уряду, котра виявляється у зменшенні витрат на науку, а також деградація ресурсної бази, як матеріально-технічної, так і кадрового потенціалу.

Ефективне та якісне забезпечення інформаційних потреб спеціалістів АПК неможливе без інформаційних ресурсів, за зберігання й нагромадження яких традиційно відповідають бібліотеки. Галузевими центрами національної системи НTI є сільськогосподарські наукові книгозбірні на чолі з Національною науковою сільськогосподарською бібліотекою НААН, що, відповідно до спільного наказу Мінагрополітики та Української академії аграрних наук "Про Центральну наукову сільськогосподарську бібліотеку УААН" № 178/45 від 01.07.2002 та Постанови Кабінету Міністрів України "Про створення Державної наукової сільськогосподарської бібліотеки Української Академії Аграрних Наук" № 1697 від 29.10. 2003, є "...координаційним і методичним центром для сільськогосподарських бібліотек ВН3 I-IV p. а. та науково-дослідних установ". ННСГБ НААН об'єднує функції, завдання й напрями наукової та загальнодержавної галузевої бібліотеки, тому ключовим напрямом іiі діяльності $\epsilon$ науководослідна робота, що передбачає реалізацію академічних проєктів і спрямована на розв'язання актуальних проблем оптимізації інформаційно-бібліотечного забезпечення потреб аграрного сектору в умовах трансформаційних процесів євроінтеграції. Зокрема, 2018 р. книгозбірня стала співвиконавцею науково-технічної програми НААН "Наукові основи ефективного функціонування та інноваційно-інвестиційного розвитку аграрної науки в конкурентних умовах міжнародної інтеграції" ("Інноваційний розвиток"), підпрограми "Наукові основи інформаційно-бібліотечного забезпечення досліджень в галузях агропромислового виробництва", працюючи в межах двох фундаментальних, одного пошукового та трьох прикладних досліджень. Пріоритетним напрямом діяльності ННСГБ НААН $\epsilon$ розкриття та репрезентація фонду наявних документів, а також забезпечення доступу до них широкому колу фізичних і віртуальних користувачів. У цьому напрямі здійснюється активне формування електронної бази даних "ЕК Украгротека". Ресурс $є$ політематичною базою даних розподілених електронних ресурсів: оцифрованих, запозичених і власної генерації, загальний обсяг якого становить понад 550 тис. записів, із них 52 тис. - на повнотекстові видання. Користувачі мають можливість доступу до 10 тис. повних текстів авторефератів аграрної тематики, понад 500 повнотекстових книг, 3 яких $200-$ із фонду цінної та рідкісної книги, більш як 28,5 тис. періодичних видань. Успішно реалізуються завдання щодо створення національної сільськогосподарської бібліографії, репрезентованої 13 біобібліографічними серіями. Відбувається оприлюднення наукових статей через міжвідомчий збірник електронного фахового видання "Історія науки і біографістика". Від 1999 р. щоквартально виходить друком реферативний журнал "Агропромисловий комплекс України", що інформує про основні вітчизняні досягнення аграрної науки й виробництва, a для виконання інформаційних запитів галузевих інститутів бібліотечні фахівці періодично готують та видають його спеціальні випуски.

Важливим напрямом діяльності ННСГБ НААН є забезпечення доступу користувачів до повнотекстових електронних документів аграрної та суміжних тематик світового інформаційного простору, зокрема до міжнародних баз даних Agris/Caris, Agricola, Hinari, Агораi Oare, Agros та інших.

ННСГБ щороку організовує та проводить курси 3 підвищення кваліфікації бібліотечних працівників мережі сільськогосподарських бібліотек Міністерства освіти і науки України та НААН шляхом поглиблення та оновлення професійних знань, умінь і навичок на основі здобутого освітньо-кваліфікаційного рівня та практичного досвіду. За час функціонування курсів майже 700 осіб прослухали лекції та отримали свідоцтва встановленого зразка. У 2018 р. курси відвідали представники 30 галузевих бібліотек (47 осіб). 
Важливим елементом інформаційного забезпечення АПК є мережа аграрних книгозбірень, загальний фонд якої станом на 01.01.2019 налічував майже 16 млн пр., обсяг повнотекстових БД - 101 од., ЕК 3237098 записів, кількість оцифрованих документів 1783 од.

За сучасних умов для забезпечення повноти колекцій аграрні бібліотеки спрямовують діяльність на кооперацію з іншими книгозбірнями мережі, об'єднання інформаційних ресурсів і надання взаємного доступу до них. Ефективною для розв'язання завдань, що постали в цьому контексті перед аграрними бібліотеками, є участь у корпоративних проєктах, котрі дають змогу вдосконалити обслуговування користувачів в єдиному електронному просторі. Зокрема, було продовжено роботу 3 наповнення галузевого корпоративного каталогу "АгроКАРС" на основі співпраці ННСГБ НААН із книгозбірнями мережі сільськогосподарських бібліотек НААН, формування баз даних нових надходжень, періодичних видань, авторефератів дисертацій, дисертацій, аналітичних статей із періодичних видань [9, с. 10-35].

Варто зазначити, що в сучасних умовах в аграрному секторі економіки України разом 3 основними видами аграрних формувань - господарські товариства, фермерські, приватні, державні підприємства тощо успішно функціонують великі аграрні підприємства чи їх об'єднання - агрохолдинги. Одним із найважливіших напрямів їхньої діяльності $\epsilon$ науковоінформаційне забезпечення АПК з актуальних питань про наявні технологічні продукти й технології через соціальні мережі та блоги; налагодження комунікації між представниками агросектору та технологічних компаній; обмін досвідом упровадження технологій на основі практичних моделей; проведення маркетингових досліджень; випуск інформаційних видань; інвестування коштів в інноваційні високотехнологічні продукти для агросектору із залученням професорськовикладацького складу та наукових співробітників.

Окрім інформаційних систем Мінекономрозвитку, МОН, НААН і підпорядкованих ним організацій та установ, а також книгозбірень і галузевих приватних компаній, важливу роль в інформаційному забезпеченні АПК відіграють також дорадчі служби, УкрIНTЕІ, УкрНДНЦ, Держстат, галузеві асоціації, інформаційні портали тощо.

Висновки. Підсумовуючи викладене, зауважимо, що нині систему інформаційного забезпечення АПК як на рівні країни, так і на рівні регіонів відрізняють такі ознаки: недосконала взаємодія іiі організаційних структур; незадовільний стан інформаційно-комунікаційних технологій та інформаційних ресурсів; низький рівень комп'ютерної й інформаційної грамотності працівників державних установ та організацій, особливо в регіонах; повільне впровадження нових методів навчання із застосуванням сучасних інформаційнокомунікаційних технологій тощо. Бракує галузевої автоматизованої інформаційної системи, що забезпечує методично організоване збирання, зберігання та взаємодію інформаційних ресурсів щодо галузевих інноваційних науково-технічних розробок і проєктів на державному, обласному та районному рівнях. Порушені проблеми призводять до того, що чинна система інформаційного забезпечення не відповідає своїй меті та не здійснює надійного та якісного інформаційного супроводу АПК.

\section{Список використаної літератури}

1. Користувачі інформації. - Режим доступу: http://um.co.ua/3/3-11/3-118262.html. — Назва з екрана (дата звернення 06.04.2018).

2. Лаврик О. Л. Современные тенденции в информационном обеспечении научно-исследовательских работ / О. Л. Лаврик, Ю. В. Мохначева, Н. Н. Шабурова. - Новосибирск, 2010. - 232 с.

3. У Мінагрополітики запрацював інформаційний центр. - Режим доступу: http://minagro.gov.ua/node/18552. — Haзва 3 екрана (дата звернення 14.04.2018).

4. Звіт про надходження інформаційних запитів за IV квартал 2018 року. - Режим доступу: http://www.minagro.gov.ua/uk/dostup-do-publichnoi-informacii?nid=26714. - Назва з екрана (дата звернення 14.04.2018).

5. Мінагрополітики запускає допоміжний інформаційний ресурс для широкого кола користувачів. — Режим доступу: https://minagro.gov.ua/ua/news/minagropolitiki-zapuskae-dopomizhniy-informatsiyniy-resurs-dlya-shirokogo-kola-koristuvachiv. - Назва з екрана (дата звернення 15.04.2018).

6. Звіт про результати аудиту ефективності використання коштів державного бюджету на наукову і організаційну діяльність президії Національної академії аграрних наук України / Рахункова Палата. — 2017. — 51 с. — Режим доступу: http://www.ac-rada.gov.ua/doccatalog/document/16754557/zvit_26-2_2017.pdf?subportal=main. — Назва 3 екрана (дата звернення 12.04.2018).

7. Постанова № 03/01 Президії НААН, протокол № 3 від 13 березня 2019 p. - Режим доступу: http:// naas.gov.ua/upload/iblock/49d/\%D0\%9F\%D0\%BE\%D1\%81\%D1\%82\%D0\%B0\%D0\%BD\%D0\%BE\%D0\%B2\%D0\%B0.pdf. - Назва з екрана (дата звернення 12.04.2019).

8. Інноваційні розробки університетів і наукових установ МОН України / колектив авторів за заг. ред. М. Стріхи та М. Ільченка. - Київ, 2017. - 278 с. — Режим доступу: https://mon.gov.ua/storage/app/media/nauka/nauka-v-universitetax/ rozrobkiuniv-monu.pdf. - Назва з екрана (дата звернення 12.04.2018).

9. Інформаційний звіт про діяльність Національної наукової сільськогосподарської бібліотеки за 2018 р. / Національна наукова сільськогосподарська бібліотека. - 2018. - 182 с.

Oksana Kapralyuk System of scientific and information support of agricultural complex of Ukraine

The article analyzes the current state of information resources formed at different levels of government. The characteristics of the national system of scientific and technical information on agriculture are presented. It is stated that the main users of scientific and technical information in the field of agriculture are the following three categories, selected according to the nature of activity: 
scientists; commodity producers; executives, managers. Features of their information support are given. It is noted that among the sectoral information systems, information systems play an important role in the development of the agro-industrial complex of the country: the Ministry of Economy, Trade and Agriculture of Ukraine, Ministry of Education and Science of Ukraine, National Academy of Agrarian Sciences of Ukraine and the systems of their subordinate organizations and institutions, as well as agricultural libraries, advisory services, UkrINTEI, State Enterprise "Ukrainian Research and Training Center for Standardization, Certification and Quality", the State Statistics Committee, industry associations, information portals and others. Together, they form an integrated information system. Effective and high-quality provision of information needs of agricultural specialists is impossible without the information resources, which are traditionally handled by the agricultural libraries headed by the National Scientific Agricultural Library (NSAL) of the National Academy of Sciences of Ukraine. The main priority of the latter is the disclosure and presentation of existing documents, as well as access to a wide range of physical and virtual users. In this direction, the active creation of its own electronic database "online catalog Ukragroteka" is active, with a total volume of more than 550 thousand records, of which 52 thousand - full-text publications. The tasks for the creation of the national agricultural bibliography, presented by 13 biobibliographic series, are successfully implemented. Since 1999 the systematic quarterly abstract journal "Agroindustrial Complex of Ukraine" has been published quarterly.

Keywords: national agricultural information resources; users of information; generators of sectoral information; NSAL NAAS; Ukragroteka electronic catalog; databases; electronic information resources; network of agricultural libraries

\title{
References
}

1. Korystuvachi informatsii (2018). Available at: http://um.co.ua/3/3-11/3-118262.html [Accessed 06.04.2018].

2. Lavrik O. L., Mohnacheva Yu. V., Shaburova N. N. (2010). Sovremennyie tendentsii v informatsionnom obespechenii nauchnoissledovatelskih rabot. Novosibirsk.

3. U Minahropolityky zapratsiuvav informatsiinyi tsentr. (2018). Available at: http://minagro.gov.ua/node/18552 [Accessed 14.04.2018].

4. Zvit pro nadkhodzhennia informatsiinykh zapytiv za IV kvartal 2018 roku. (2018). Available at: http://www.minagro.gov.ua /uk/dostup-do-publichnoi-informacii?nid=26714 [Accessed 14.04.2018].

5. Minahropolityky zapuskaie dopomizhnyi informatsiinyi resurs dlia shyrokoho kola korystuvachiv. (2018). Available at: https://minagro.gov.ua/ua/news/minagropolitiki-zapuskae-dopomizhniy-informatsiyniy-resurs-dlya-shirokogo-kola-koristuvachiv [Accessed 15.04.2018].

6. Zvit pro rezultaty audytu efektyvnosti vykorystannia koshtiv derzhavnoho biudzhetu na naukovu $i$ orhanizatsiinu diialnist prezydii Natsionalnoi akademii ahrarnykh nauk Ukrainy (2017). Available at: http://www.ac-rada.gov.ua/doccatalog/ document/16754557/zvit_26-2_2017.pdf?subportal=main [Accessed 12.04.2018].

7. Postanova № 03/01 Prezydii NAAN, protokol № 3 vid 13 bereznia 2019 r. Available at: http:// naas.gov.ua/upload/iblock/49d/\%D0\%9F\%D0\%BE\%D1\%81\%D1\%82\%D0\%B0\%D0\%BD $\%$ D0 $\%$ BE $\%$ D0 $\%$ B2 $\%$ D0 $\% B 0 . p d f$ [Accessed 12.04.2019].

8. Kolektyv avtoriv za zah. red. M. Strikhyta M. Ilchenka. (2017). Innovatsiini rozrobky universytetiv i naukovykh ustanov MON Ukrainy. Kyiv. Available at: https://mon.gov.ua/storage/app/media/nauka/nauka-v-universitetax/rozrobkiuniv-monu.pdf [Accessed 12.04.2018].

9. Informatsiinyi zvit pro diialnist Natsionalnoi naukovoi silskohospodarskoi biblioteky za 2018 r. (2018). Natsionalna naukova silskohospodarska biblioteka.

Надійшла до редакції 17 грудня 2019 року

\section{3 АРХІВУ КНИЖКОВОї ПАЛАТИ УКРАЇНИ}

\author{
УДК 655.59:[378.4:050](477)"1917/1919"(045) \\ DOI: $10.36273 / 2076-9555.2020 .2(283) .42-47$
}

Лариса Дояр,

кандидат історичних наук, дочент, стариий науковий співробітник Книжкової палати України, e-mail:arkhiv@ukrbook.net ORCID: https://orcid.org/0000-0003-0789-2462

\section{Наукова періодика Украӥни 1917-1919 рр.: аналіз академічних видань (за матеріалами Книжкової палати України)}

Стаття продовжує низку авторських розвідок, присвячених періодичним виданням, що виходили на зорі новітньоі історії Украӥни, коли, внаслідок руйнаиії Російської імперії, відбувалася розбудова нашої національної держави. У пропонованій статті порушено проблему діяльності провідних закладів вищої освіти на теренах тогочасної Украйни, зокрема Університету Св. Володимира у Києві, Технологічного інституту імператора Олександра III у Харкові, Катеринославського гірничого інституту, Харківського університету, Київського та Харківського комерчійних інститутів тощо. У дослідженні використано збірники наукових праџь, укладених упродовж 1917-1919 рр. науковиями та співробітниками зазначених установ. На основі проведеного контент-аналізу періодичних видань, щзо виходили у зазначених закладах освіти, авторка дійшла кількох висновків, а саме: вища освіта революиійної Украӥни все ще залишалася під ідейним впливом Росії (чи то иарської, чи то республіканської); професорсько-викладацький склад циих установ чинив неабиякий спротив оголошеній Украӥнською Центральною Радою політииі українізацї; у навчальних закладах, заснованих за часів імператорського правління, навіть в умовах кардинальних револючійних змін продовжували панувати сталі освітянські традииї (землячтва, благодійні внески, іменні стипендї на підтримку різних категорій студентства); заклади вищої 